\title{
The heterogeneity of effects of preschool education on cognitive outcomes in Latin America
}

\author{
Juan Antonio Dip and Luis Fernando Gamboa
}

\begin{abstract}
This study applies a propensity score matching model to quantify the significance of preschool education in short- and medium-term academic results in several Latin American countries, using data from the Third Regional Comparative and Explanatory Study (TERCE) conducted among third and sixth grade pupils. The results vary by country and grade, with standard deviations ranging between 0.05 and 0.3. Third-grade reading and mathematics scores show an effect greater than 0.10 standard deviations in at least 10 countries, while 7 countries show the same effect for the three tests conducted in sixth grade.
\end{abstract}

\section{Keywords}

Preschool education, children, child development, academic achievement, educational indicators, Latin America

\section{JEL classification}

$$
\text { C14, H4, } 121
$$

\section{Authors}

Juan Antonio Dip holds a doctorate in economics and is a faculty member in the Department of Economics and Finance, Faculty of Economics, Universidad Nacional de Misiones, Argentina. Email: dip@fce.unam.edu.ar.

Luis Fernando Gamboa holds a doctorate in economics and is a faculty member in the Department of Economics, Universidad Jorge Tadeo Lozano, Colombia. Email: luisfw.gamboan@utadeo.edu.co. 


\section{Introduction}

The importance of assessing the success of educational policies is undisputed, and intervention in early childhood offers greater room for manoeuvre and the effectiveness of resources is economically significant (Heckman, Pinto and Savelyev, 2013). This paper aims to identify the effect of preschool education on the scores of third- and sixth-grade pupils in the mathematics, reading and writing and natural science tests of the Third Regional Comparative and Explanatory Study (TERCE) conducted in 2013 -the third of a series of regional assessments, following the First Regional Comparative and Explanatory Study (PERCE) and the Second Regional Comparative and Explanatory Study (SERCE). ${ }^{1}$ The studies are comparable, as are the data from the different countries, because of the statistical methodology and the two-stage stratified cluster sample selection method.

The issue is critical, reflecting the institutional interest in improving the living conditions of Latin Americans given the region's low averages in human capital levels as well as the need to improve equality in these countries. Recently, the differences in cognitive achievement between Latin American countries and their counterparts in the developed world have been made apparent in the results of the Programme for International pupil Assessment (PISA) and the Trends in International Mathematics and Science Study (TIMSS) tests. Investment in preschool education programmes has both direct and indirect positive effects. First, it builds capacity in children at a lower cost compared with older populations; second, it reduces barriers to the participation of mothers in the workforce (Cascio, 2015; Shah and others, 2017; Heckman, Pinto and Savelyev, 2013; Loeb and others, 2007; Behrman, Cheng and Todd, 2004; Skibbe and others, 2011; Shonkoff and Phillips, 2000).

These effects are sustained over the long run; others decline over time, but remain apparent several years later (Nores and Barnett, 2010; Berlinski, Galiani and Manacorda, 2008; Magnuson, Ruhm and Waldfogel, 2007a and 2007b). The literature supports the view that such programmes have positive, albeit modest, effects on children that may persist over time and is therefore a key area for intervention and global monitoring (UNESCO, 2014).

According to the United Nations Educational, Scientific and Cultural Organization (UNESCO) (2013), the average net enrolment ratio in pre-primary education jumped from 55.5\% to 66\% between 1990 and 2010. However, pre-primary coverage varies greatly in these countries (between 40\% and 90\%). For example, enrolment ratios in Mexico and Uruguay were twice those of the Plurinational State of Bolivia and Paraguay in 2010. In 2014, net pre-primary coverage increased, exceeding 85\% in Peru and Uruguay; in contrast, the countries of Central America (Costa Rica, Guatemala, Honduras and Panama) did not register significant progress, with net enrolment rates below 53\%.

However, the fact that preschool attendance is an educational service gives rise to several challenges. First, there is no standard of quality against which the package of actions and the components used to deliver it can be fully compared. Second, the number of years of attendance depends on both supply and demand.

In Latin America, there is little evidence on the causal effects of preschool that can be supported by internationally comparable tests. Recent literature provides a detailed description of the problems of access to and coverage of early education in Latin America. Examples include the studies conducted by the Regional Program for Social Policy in Latin America (SOPLA) (2014) and by Gamboa and Krüger (2016), which present an overview of the country-level differences in coverage indicators that illustrate the adverse access conditions facing the most vulnerable populations. Gamboa and Krüger use a non-parametric method to decompose the results of the 2012 PISA cycle to show the effect of early education on reading and mathematics in Argentina, Brazil, Chile, Colombia, Mexico, Peru and

1 TERCE and SERCE are comparable. For details on the historical evolution of this study, see [online] http://www.unesco.org. 
Uruguay. Their analysis reveals the existence of socioeconomic segregation in terms of access and score gaps that widen the longer the period of preschool attendance.

The common finding in these studies is that in Latin American countries there are significant cognitive gaps between children in wealthier and poorer households when they enter school and these gaps persist over time (Schady and others, 2015). Araujo, Dormal and Schady (2017) present an interesting discussion of the findings on the effects of the quality of child care, with an extensive review of the literature.

In Chile, the Ministry of Education (MINEDUC, 2014) provides studies on the short-, medium- and long-term effects of attending preschool. Overall, the studies show that the effects of attending preschool are positive and significant, although there is no conclusive evidence supporting the universality of the impact of preschool attendance on the comprehensive development of children (p. 22).

Other studies, including Bernal and others (2012) and Bernal and Camacho (2012), go further and prove the causal effect of early education programmes on children's education outcomes. Bernal and others (2015) show that a transition in the education model in Colombia from small community nurseries to large child-care centres catering to 150 children or more did not improve quality. Other more detailed studies estimate a positive impact of early education programmes of about 0.20 standard deviation in cognitive skills scores (see Berlinski and Schady, 2015). The contributions of the present paper are multifarious. First, as mentioned above, it emphasizes the need to address performance differentials in assessments such as PISA tests that are conducted at later stages of the educational cycle. Second, it provides evidence on the cognitive effects of increasing access to preschool after controlling for other variables associated with pupils, their families, schools and education systems. Third, it underscores the need for cooperation to learn from different coverage initiatives in neighbouring countries. These aspects aside, some caution in the interpretation of results is warranted as variables that are not always observable may influence the findings.

The empirical strategy uses a propensity score matching model that reduces the bias generated by unobservable variables.

The results are heterogeneous but positive in the countries participating in TERCE. In Central American countries, there appears to be evidence of a greater effect on test scores than in other countries, but there is no pattern of an increase or decrease in effect between countries and between third and sixth grade.

The article is divided into five sections including this introduction. Section II presents the empirical strategy for comparing performance according to the levels of exposure to a preschool programme. Section III describes the data used to assess the effect and section IV presents the results. The article concludes with some recommendations for consideration.

\section{Empirical strategy}

In cognitive tests (mathematics, reading and natural sciences) of the individual $i$ in school $s$ in municipality $m$ in country $j$, standardized scores $\left(Y_{i s m j}\right)$ are determined by factors associated with the individual and his or her family $(X)$, education establishment variables $(Z)$ and country- or region-specific variables $(W)$.

$$
Y_{i s m j}=a+\operatorname{Pre}_{i j}+\beta_{1} X+\beta_{2} Z+\beta_{3} W+\varepsilon_{i}
$$

The variables considered within vector $X$ include age, gender, household wealth and parents' educational level. Controls for the school $(Z)$ include whether the school is urban or rural and State-run or private, and an establishment quality indicator calculated from the classroom climate is also introduced. However, there is no control for parent motivation or pupil ability. 
If it is assumed that these are randomly distributed, where $E(X / \varepsilon)=0$, then it is possible to estimate the preschool effect using an ordinary least squares model.

However, greater parent motivation can increase and improve educational practices in the home, which would mean that the effect of preschool is overestimated. If the correlation between ability and performance is positive and the correlation between ability and parents' motivation with respect to education is also positive, the estimator $\left(\mathrm{Pre}_{i j}\right)$ will be greater than the true value. In addition, ordinary least squares regression may miss the heterogeneous impact of treatment (Black, 2015), which, in this case, is given by preschool attendance. To control for these limitations, a quasi-experimental method - propensity score matching - is used to evaluate the causal effect.

Proposed by Rosenbaum and Rubin (1983), this matching method can be used to correct selection bias on the question of whether children from better socioeconomic backgrounds tend to start their education at earlier ages and have a greater likelihood of attending preschool. Preschool attendance is determined by parents' decisions and is therefore not random. Consequently, children's measurable and non-measurable characteristics are associated with the likelihood of attending preschool (treatment) and with performance (standardized tests). Propensity score matching assumes that there is a vector of $X$ observable covariates, such that, after controlling for those covariates, the potential outcomes are independent of the treatment assignment (conditional independence) and that, for each value of $X$, there is a positive probability of being treated and not treated (common support).

The strategy adopted estimates the causal effect of attending preschool on academic achievement - measured through various standardized TERCE tests - as well as the average treatment effect on the treated (ATT). According to Heckman and Robb (1986), the estimation of the average effect on the treated is valuable for answering research questions related to social policy development, and particularly so with regard to educational policies that aim to expand compulsory preschool education.

To this end, treatment, outcome and the relevant covariates must be identified (for further details see Caliendo and Kopeinig, 2008 and Stuart, 2010). For this study, the treatment variable was PREKFOR6, which takes the value 1 if the pupil attended preschool between 4 and 6 years of age and 0 if he/she did not. The outcome variable is the z-score (with a mean of 0 and a standard deviation of 1 ) obtained by third-grade pupils from the participating countries in reading and mathematics and by sixth-grade pupils in reading, mathematics and natural sciences. ${ }^{2}$

Covariates may be selected for matching based on the association between the covariates and treatment and outcome (Stuart, 2010), however Brookhart and others (2006) suggest that variables that are unrelated to an exposure effect but related to the outcome should always be included in a propensity score model as this will increase the precision of the estimated exposure effect without increasing bias. Taking into account the above and the existing literature on preschool education, the covariates included are those considered in the ordinary least squares model and parent expectations were included in the analysis.

The matching technique was then chosen based on the standardized mean difference of covariates. Kernel matching was selected to calculate the average treatment effect on the treated because the variance was lower than that derived using the other methods tested. For all models (each test subject and for each participating country), two indicators proposed by Rubin (2001) were used to determine the balance achieved with the propensity score: Rubin's B, defined as the standardized mean difference of the linear index of the propensity score of the treated and the untreated group in the matched sample; and Rubin's R, which is the ratio of the propensity score's variance in the treated

\footnotetext{
2 Although the tests use a scaled score with a mean of 700 , the outcome variable has been rescaled to allow interpretation of the results in terms of standard deviations.
} 
and untreated sample. Rubin (2001) suggests that a B value of less than 0.25 indicates that the covariates are balanced. The variance ratio $R$ should remain close to 1 but values between 0.5 and 2 are considered acceptable (see table 5).

All calculations yielded values for $B$ of less than 0.25 and values for $R$ that were close to 1 . In this methodology, the interpretation of the average treatment effect on the treated depends on the standard errors that are calculated. While the focus in literature has been on adjusting standard errors through bootstrapping, Abadie and Imbens (2005) demonstrate that bootstrap standard errors are not valid as the basis for inference with simple nearest-neighbour matching estimators. However, the reservations expressed about bootstrapping standard errors in matching do not apply to the kernel method, because it does not run into the discontinuities that arise in nearest-neighbour matching (Wagstaff, 2007).

To generalize the results of estimates obtained from data samples, sample weights must be used in propensity score matching; failure to do so would limit the external validity of the results given that the population inferences are based on a non-representative sample. Therefore, sample weights and sample design are integral to the process of estimating propensity scores and using the propensity score to determine the treatment effect. Two types of treatment effects are thus distinguished: the sample average treatment effect on the treated, where survey weights are incorporated only in the calculation of the propensity score; and the population average treatment effect on the treated, where survey weights and the propensity score weights are multiplied to form a new composite weight that is used in a weighted regression (DuGoff, Schuler and Stuart, 2014).

\section{Data}

Coordinated by UNESCO, TERCE was conducted in 2013 among more than 100,000 school children in 15 Latin American countries (Argentina, Brazil, Chile, Colombia, Costa Rica, Dominican Republic, Ecuador, Guatemala, Honduras, Mexico, Nicaragua, Panama, Paraguay, Peru and Uruguay). It assesses school performance in mathematics and language (reading and writing) in third grade, with the inclusion of natural sciences in sixth grade. To enable comparisons at country level and over time with the 2006 SERCE, a two-stage stratified cluster sample selection method was used for TERCE. In the first stage, a probability proportional to size method was used to select schools (in each explicit stratum). In the second stage, a class was selected randomly and all pupils in the class were included in the sample. This sampling technique is useful for making inferences regarding the education system because it recognizes that there are different levels of inter- and intra- school variability ${ }^{3}$ (further information on sample representativeness is available in UNESCO, 2016). Annex A1 shows that the sample sizes are considerable for each of the participating countries once the sample weights provided by TERCE are taken into account - for the third-grade language test, there were more than 2600 pupils in the country with the smallest absolute sample size. As part of the construction of the cognitive tests, the curricular frameworks of the participating countries were reviewed to determine performance levels by subject area. Consequently, TERCE can help to enrich the literature on educational assessment in the region because it is based on common content and uses a sample design similar to that of other assessments such as PISA or the Progress in International Reading Literacy Study (PIRLS). The variable for identifying children who attended preschool between the ages of 4 and 6 was created by TERCE.

Before analysing the overall results obtained by the participating countries, it is useful to review the aggregate indicators pertaining to the current state of the education sector (see table 1). Despite the progress made in Latin America in reducing poverty, there are still countries where poverty rates

\footnotetext{
3 In addition, it uses senate weights, which are a re-scaling of the originally calculated sample weight within each country to make the population of each country equal to a constant. They are used to perform comparative estimates or analyses across countries, regardless of their population size.
} 
are above 10\%, such as Colombia, Ecuador, El Salvador Honduras and Nicaragua, while others such as Argentina, Chile and Costa Rica have rates below 5\%. The geographic distribution of population shows that some countries, such as Argentina or Uruguay, are highly urbanized; others have large rural populations - commonly the case in Central American countries, as seen for Guatemala (48\%) and Honduras (45\%).

Table 1

Socioeconomic indicators

(Percentages)

\begin{tabular}{|c|c|c|c|c|c|c|c|}
\hline \multirow[t]{2}{*}{ Country } & \multirow{2}{*}{$\begin{array}{l}\text { Poverty rates } \\
\text { (in percentages) }\end{array}$} & \multirow{2}{*}{$\begin{array}{l}\text { Rural population } \\
\text { (as percentages of } \\
\text { total population) }\end{array}$} & \multirow{2}{*}{$\begin{array}{c}\text { Public spending } \\
\text { on education } \\
\text { (percentages of GDP) }^{\star \star *}\end{array}$} & \multicolumn{4}{|c|}{$\begin{array}{l}\text { Participation: net enrolment rate, by level of education } \\
\text { (in percentages) }^{\star \star \star \star}\end{array}$} \\
\hline & & & & Preschool & Primary & Secondary & Tertiary \\
\hline Argentina & 4.3 & 8 & 5.33 & 72.47 & 99.3 & 88.2 & 82.9 \\
\hline Brazil & 7.6 & 14 & 5.99 & 81.98 & 92.7 & 81.3 & 50.6 \\
\hline Chile & 2 & 10 & 4.92 & 80.76 & 94.3 & 87.9 & 88.5 \\
\hline Colombia & 13.2 & 24 & 4.49 & 78.29 & 90.6 & 78.2 & 55.6 \\
\hline Costa Rica & 3.9 & 23 & 7.18 & 50.36 & 96.4 & 79.3 & 53.6 \\
\hline Ecuador & 10.2 & 36 & 4.96 & 66.14 & 91.2 & 85.4 & 40.4 \\
\hline El Salvador & 11.3 & 33 & 3.55 & 42.94 & 91.2 & 68.7 & 55.5 \\
\hline Guatemala & 24 & 48 & 2.96 & 41.91 & 85.4 & 48.1 & 29.1 \\
\hline Honduras & 31.2 & 45 & 5.87 & 68.72 & 93 & 49.4 & 21.8 \\
\hline Mexico & 11 & 21 & 5.31 & - & 95 & 90.5 & 22 \\
\hline Nicaragua & 17.1 & 41 & 4.49 & 46.83 & 96.9 & 48.9 & 29.9 \\
\hline Peru & 9 & 21 & 9 & 88.36 & 94 & 77.6 & - \\
\hline Dominican Republic & 9.1 & 21 & - & 43.16 & 86.89 & 66 & 50.12 \\
\hline Uruguay & 1.3 & 5 & 4.36 & 88.23 & 94.2 & 76.3 & - \\
\hline
\end{tabular}

Source:Prepared by the authors, on the basis of information from United Nations Educational, Scientific and Cultural Organization (UNESCO).

Note: $\quad$ * Based on a poverty line of US\$ 3.10 per day (in 2011 PPP dollars); ${ }^{*}$ Latest data on education available from UNESCO Institute for Statistics; ${ }^{\star \star \star}$ Data refer to 2015 except for Argentina, Honduras and Nicaragua (2010) and Panama (2014).

While there is not much disparity in the levels of government spending on education, it is possible to distinguish two groups: countries that spend more than 5\% of GDP on education (seven countries, with Peru spending the most in recent years) and those with lower spending, with Guatemala being the country that dedicates the lowest share of public resources to education.

There is, however, great variation among countries in terms of participation rates in higher levels of education: Argentina and Chile stand out with enrolment rates above $83 \%$ at all levels, while in Mexico, coverage of primary and secondary education is high but declines at the tertiary level. At the other end of the spectrum, Guatemala and Honduras register enrolment rates below 50\% in secondary and tertiary education.

As can be seen from the performance rankings for subjects and by country (see table 2), more than 185 points separate the country with the highest scores in third grade (Chile) from the country with the lowest scores (Dominican Republic); this differential narrows in sixth grade scores. Costa Rica and Mexico are among the countries with the highest scores, while the Dominican Republic and Paraguay are among the lowest in the rankings. The results show varying levels of heterogeneity within each country: there is high dispersion Colombia and low dispersion in Nicaragua.

Moreover, an analysis of average differences by population group and school type (rural schools and urban public schools) indicates that girls and boys who attend State-run schools in urban areas perform better in all countries, regardless of grade or type of test. This bias is more pronounced in countries with large rural populations (Guatemala, Honduras and Nicaragua) than in those with small rural populations (Argentina, Chile and Uruguay) (see annex tables A1.4 and A1.5). 
Table 2

TERCE scores, by subject and by country (Means and standard deviation)

\begin{tabular}{|c|c|c|c|c|c|c|c|c|c|c|}
\hline & \multicolumn{4}{|c|}{ Reading } & \multicolumn{4}{|c|}{ Mathematics } & \multirow{2}{*}{\multicolumn{2}{|c|}{$\begin{array}{c}\text { Natural sciences } \\
\text { Sixth grade }\end{array}$}} \\
\hline & \multicolumn{2}{|c|}{ Third grade } & \multicolumn{2}{|c|}{ Sixth grade } & \multicolumn{2}{|c|}{ Third grade } & \multicolumn{2}{|c|}{ Sixth grade } & & \\
\hline & Mean & $\begin{array}{l}\text { Standard } \\
\text { deviation }\end{array}$ & Mean & $\begin{array}{l}\text { Standard } \\
\text { deviation }\end{array}$ & Mean & $\begin{array}{l}\text { Standard } \\
\text { deviation }\end{array}$ & Mean & $\begin{array}{l}\text { Standard } \\
\text { deviation }\end{array}$ & Mean & $\begin{array}{l}\text { Standard } \\
\text { deviation }\end{array}$ \\
\hline Argentina & 703 & 4.89 & 707 & 4.5 & 717 & 4.83 & 722 & 4.14 & 700 & 4.65 \\
\hline Brazil & 712 & 4.99 & 721 & 4.91 & 727 & 6.05 & 709 & 5.29 & 700 & 4.52 \\
\hline Chile & 802 & 3.96 & 776 & 3.23 & 787 & 4.04 & 793 & 4.24 & 768 & 4.63 \\
\hline Colombia & 714 & 8.33 & 726 & 5.49 & 694 & 7.8 & 705 & 5.45 & 733 & 4.57 \\
\hline Costa Rica & 754 & 3.24 & 755 & 2.8 & 750 & 2.86 & 730 & 3.09 & 756 & 3.14 \\
\hline Ecuador & 698 & 4.72 & 683 & 5.14 & 703 & 4.75 & 702 & 4.64 & 711 & 4.57 \\
\hline Guatemala & 678 & 3.87 & 678 & 3.2 & 672 & 3.28 & 672 & 2.96 & 684 & 3.43 \\
\hline Honduras & 681 & 4.14 & 662 & 6.19 & 680 & 4.97 & 661 & 4.01 & 668 & 3.52 \\
\hline Mexico & 718 & 3.25 & 735 & 3.34 & 741 & 3.26 & 768 & 3.51 & 732 & 3.23 \\
\hline Nicaragua & 654 & 2.84 & 662 & 2.72 & 653 & 3.07 & 643 & 2.44 & 668 & 3.38 \\
\hline Paraguay & 653 & 4.81 & 652 & 3.99 & 652 & 5.42 & 641 & 3.75 & 646 & 4.12 \\
\hline Peru & 719 & 3.91 & 703 & 3.39 & 716 & 4.1 & 721 & 3.92 & 701 & 3.61 \\
\hline Dominican Republic & 614 & 3.5 & 633 & 3.29 & 602 & 3.68 & 622 & 2.31 & 632 & 3.01 \\
\hline Uruguay & 728 & 7.15 & 736 & 5.02 & 742 & 7.96 & 765 & 6.38 & 725 & 6.7 \\
\hline Mean & 700 & 1.22 & 700 & 1.08 & 700 & 1.28 & 700 & 1.06 & 700 & 1.07 \\
\hline
\end{tabular}

Source: United Nations Educational, Scientific and Cultural Organization (UNESCO), TERCE: Learning Achievements, Executive Summary, Santiago, 2016.

The sociodemographic characteristics among the selected sample of pupils from the TERCE test are highly heterogeneous. There is a slight predominance of girls in both grades at country level and of pupils from urban schools (this is not the case in the Central American countries). Annex A5 shows that with the exception of Chile, more than $65 \%$ of pupils in third and sixth grade have mothers or fathers with low levels of education (below ISCED-P level 3) (see annex table A1.5).

An alternative method for measuring the effect size of preschool attendance on TERCE scores is Cohen's $d$ (Cohen 1988 and 1992), which expresses the mean difference between two groups in standard deviation units. The author posits that a value of $d=0.8$ is a large effect, $d=0.5$ is a moderate effect, and $d=0.2$ a small effect. Ideally, the size of the effect should be compared to that of other effects found in the literature on similar topics. Thus, Wen and others (2012), when comparing differences in the effect of one or two years' of preschool attendance on mathematics and language scores, find $d$ values in the range of $0.27-0.96$ and classify them as moderate and large. In a recent study on the effect of preschool education on mathematics, vocabulary and executive function outcomes at first and second grade, Shah and others (2017) observed that $d$ values ranged from 0.22 to 0.40 .

As table 3 shows, the effect sizes (original sample) can be classified as small and moderate, with a range of values of $0.32<d \leqq 0.75$ for countries and for each of the tests (see annex table A1.3 for the values found after propensity score matching).

The smallest effect size is seen in Argentina for the sixth-grade natural sciences test $(d=0.32)$ and the largest effect size corresponds to Honduras for the third-grade reading test $(d=0.75)$. Furthermore, a divergent pattern can be observed with respect to the increase or decrease in the effect size when comparing third and sixth grades. For example, in mathematics, the effect size decreases in countries such as Argentina, Chile, Colombia and Uruguay, while it increases in Brazil, Costa Rica and Peru. However, for all countries and for all the tests, the effect size classified as small for third grade remained unchanged for sixth grade and the moderate effect size also remained unchanged.

\footnotetext{
4 Level 3 of the International Standard Classification of Education (ISCED) classification for education programmes (ISCED-Programmes or ISCED-P) corresponds to upper secondary education.
} 
Table 3

Cohen's $d$ effect size, original sample

\begin{tabular}{|c|c|c|c|c|c|}
\hline \multirow{2}{*}{ Country } & \multicolumn{2}{|c|}{ Mathematics } & \multicolumn{2}{|c|}{ Reading } & \multirow{2}{*}{$\begin{array}{c}\text { Natural sciences } \\
\text { Sixth grade } \\
\end{array}$} \\
\hline & Third grade & Sixth grade & Third grade & Sixth grade & \\
\hline Argentina & 0.41 & 0.38 & 0.41 & 0.4 & 0.32 \\
\hline Brazil & 0.48 & 0.56 & 0.45 & 0.64 & 0.50 \\
\hline Uruguay & 0.58 & 0.57 & 0.50 & 0.53 & 0.55 \\
\hline Paraguay & 0.60 & 0.64 & 0.73 & 0.74 & 0.68 \\
\hline Colombia & 0.67 & 0.66 & 0.69 & 0.69 & 0.52 \\
\hline Mexico & 0.53 & 0.45 & 0.53 & 0.51 & 0.45 \\
\hline Costa Rica & 0.46 & 0.51 & 0.49 & 0.50 & 0.45 \\
\hline Peru & 0.58 & 0.62 & 0.58 & 0.67 & 0.54 \\
\hline Ecuador & 0.34 & 0.38 & 0.41 & 0.51 & 0.41 \\
\hline Nicaragua & 0.53 & 0.51 & 0.53 & 0.53 & 0.53 \\
\hline Guatemala & 0.75 & 0.57 & 0.74 & 0.61 & 0.60 \\
\hline Honduras & 0.77 & 0.66 & 0.75 & 0.73 & 0.66 \\
\hline Dominican Republic & 0.54 & 0.42 & 0.52 & 0.47 & 0.45 \\
\hline Chile & 0.43 & 0.38 & 0.40 & 0.33 & 0.34 \\
\hline
\end{tabular}

Source: Prepared by the authors.

Note: According to the size of the coefficient $d$, the effect can be classified as: very small $(d \leqq 0.20)$, small $(0.20<d \leqq 0.50)$, moderate $(0.50<d \leqq 0.80)$ and large $(d>0.80)$. Calculated for original sample.

\section{Results}

The authors estimated the effect using an ordinary least squares model with individual, family, school and city controls for each subject and for each country then presented the results obtained using the synthetic control method generated by propensity score matching. The findings show no evidence of a significant effect of preschool attendance on TERCE test scores, with a few exceptions (see table 4). That notwithstanding, the aforementioned discussion on the importance of isolating the effect of hidden variables or, at least, of considering synthetic controls, contributed to the propensity score matching results.

To ensure clarity of the propensity score matching results, the variables were first standardized to have a mean of 0 and a standard deviation of 1 before presenting the estimated coefficients of the standardized variables. ${ }^{5}$ This provides a better understanding of the effects, since regional differences in development are such that a given gross change in a subject may have significantly different relative effects.

The average treatment effect on the treated was calculated using various specifications in line with different controls. The decision was taken based on the $B$ and $R$ values proposed by Rubin (2001) in different types of matching (nearest neighbour 1:1, caliper 1:1 with replacement, and kernel) without initially observing the value of the average treatment effect on the treated. Kernel matching was thus selected, with the covariates described above. However, as adequate balance was not achieved on some covariates (e.g. gender) in some countries, a model excluding this variable was tested and there was no substantial change in the results.

\footnotetext{
5 The coefficients for the propensity score matching estimates (sample average treatment effect on the treated) are included in
} annex table A1.2. 
Table 4

Results of ordinary least squares regression ${ }^{\mathrm{a}}$

\begin{tabular}{|c|c|c|c|c|c|c|c|c|c|c|c|c|c|}
\hline & Argentina & Brazil & Uruguay & Paraguay & Colombia & Mexico & Peru & Ecuador & Nicaragua & Guatemala & Honduras & $\begin{array}{l}\text { Dominican } \\
\text { Republic }\end{array}$ & Chile \\
\hline & \multicolumn{13}{|c|}{ Third grade } \\
\hline \multicolumn{14}{|l|}{ Reading } \\
\hline \multirow[t]{2}{*}{ Preschool } & $0.181^{\star \star}$ & 0.0878 & 0.0699 & 0.146 & 0.175 & 0.0264 & $0.0961^{\star \star}$ & $0.0995^{\star \star}$ & 0.104 & $0.122^{\star \star}$ & 0.154 & 0.0882 & 0.0390 \\
\hline & $(0.0708)$ & 0 & (0.0953) & 0 & 0 & 0 & $(0.0417)$ & $(0.0497)$ & $(0.0643)$ & $(0.0553)$ & 0 & $(0.0690)$ & 0 \\
\hline N & 917 & 1339 & 994 & 1342 & 1666 & 1922 & 2362 & 1755 & 1384 & 1931 & 1624 & 1092 & 2224 \\
\hline R-squared & 0.233 & 0.261 & 0.350 & 0.198 & 0.342 & 0.270 & 0.255 & 0.285 & 0.209 & 0.313 & 0.211 & 0.165 & 0.184 \\
\hline \multicolumn{14}{|c|}{ Mathematics } \\
\hline \multirow[t]{2}{*}{ Preschool } & $0.173^{\star \star}$ & 0.130 & 0.0577 & 0.204 & 0.103 & 0.113 & 0.0654 & 0.0472 & $0.101^{*}$ & $0.0932^{*}$ & 0.0874 & 0.0784 & 0.0386 \\
\hline & $(0.0769)$ & 0 & $(0.0823)$ & 0 & 0 & 0 & $(0.0465)$ & $(0.0466)$ & $(0.0560)$ & $(0.0502)$ & 0 & $(0.0615)$ & 0 \\
\hline N & 914 & 1337 & 995 & 1324 & 1657 & 1910 & 2342 & 1735 & 1369 & 1907 & 1615 & 1091 & 2217 \\
\hline \multirow[t]{2}{*}{ R-squared } & 0.199 & 0.287 & 0.316 & 0.147 & 0.349 & 0.258 & 0.243 & 0.178 & 0.187 & 0.334 & 0.176 & 0.165 & 0.192 \\
\hline & \multicolumn{13}{|c|}{ Sixth grade } \\
\hline \multicolumn{14}{|l|}{ Reading } \\
\hline \multirow[t]{2}{*}{ Preschool } & 0.0298 & $0.277^{\star \star \star}$ & 0.177 & $0.142^{\star \star}$ & 0.172 & 0.131 & $0.196^{\star \star \star}$ & 0.174 & $0.151^{\star \star \star}$ & 0.0721 & 0.0904 & $0.101^{*}$ & $0.0985^{\star \star}$ \\
\hline & $(0.0479)$ & $(0.0812)$ & 0 & $(0.0554)$ & 0 & 0 & (0.0373) & 0 & $(0.0474)$ & $(0.0492)$ & 0 & $(0.0561)$ & $(0.0426)$ \\
\hline N & 1626 & 1224 & 1304 & 1592 & 2189 & 2331 & 2753 & 2225 & 1820 & 2350 & 2169 & 1706 & 2695 \\
\hline R-squared & 0.173 & 0.211 & 0.199 & 0.322 & 0.176 & 0.217 & 0.320 & 0.245 & 0.190 & 0.260 & 0.220 & 0.177 & 0.143 \\
\hline \multicolumn{14}{|l|}{ Mathematics } \\
\hline \multirow[t]{2}{*}{ Preschool } & 0.0792 & $0.169^{\star \star}$ & 0.151 & $0.160^{\star \star \star}$ & 0.171 & 0.166 & $0.244^{\star \star \star}$ & 0.0752 & $0.133^{\star \star \star}$ & $0.114^{\star \star}$ & 0.147 & $0.151^{\star \star \star}$ & $0.155^{\star \star \star}$ \\
\hline & $(0.0555)$ & (0.0728) & 0 & $(0.0522)$ & 0 & 0 & $(0.0434)$ & 0 & $(0.0409)$ & $(0.0477)$ & 0 & $(0.0475)$ & $(0.0452)$ \\
\hline N & 1521 & 1207 & 1259 & 1538 & 2108 & 2289 & 2733 & 2181 & 1739 & 2283 & 2089 & 1539 & 2649 \\
\hline R-squared & 0.132 & 0.178 & 0.213 & 0.171 & 0.144 & 0.168 & 0.263 & 0.169 & 0.129 & 0.215 & 0.111 & 0.089 & 0.113 \\
\hline
\end{tabular}

Source: Prepared by the authors.

Note: Standard errors in parentheses: ${ }^{* *} p<0.01,{ }^{* *} p<0.05,{ }^{*} p<0.1$.

a All regressions include controls for pupils, family and school.

Table 5 shows the results of the average treatment effect on the treated for all countries for the tests administered in third grade and in sixth grade. This was done using the methodology proposed by DuGoff, Schuler and Stuart (2014) for incorporating survey weights with propensity score methods to estimate the average treatment effect on the treated. Lastly, for clarity and robustness of the results, one covariate (pupil gender) was removed from the model in the propensity score analysis. The aim was to observe significant differences in the estimations and this demonstrated the stability of the calculations. The sensitivity analysis proposed by Rosenbaum (2002) was conducted. The odds ratios (gamma $(\Gamma)$ values) at which estimates are sensitive to hidden bias range from 1.05 to $1.65 .{ }^{6}$ Most countries were sensitive from $\Gamma$ values of 1.20 (95\% confidence interval). ${ }^{7}$

\footnotetext{
6 Because of difficulty accounting for the existing problems concerning the variability of the data for Panama since the creation of the database, the authors opted not to include it in the study.

7 Due to the extent of the calculations, they have not been included in the document but are available on request.
} 
Table 5

Propensity score matching results: population average treatment effect on the treated

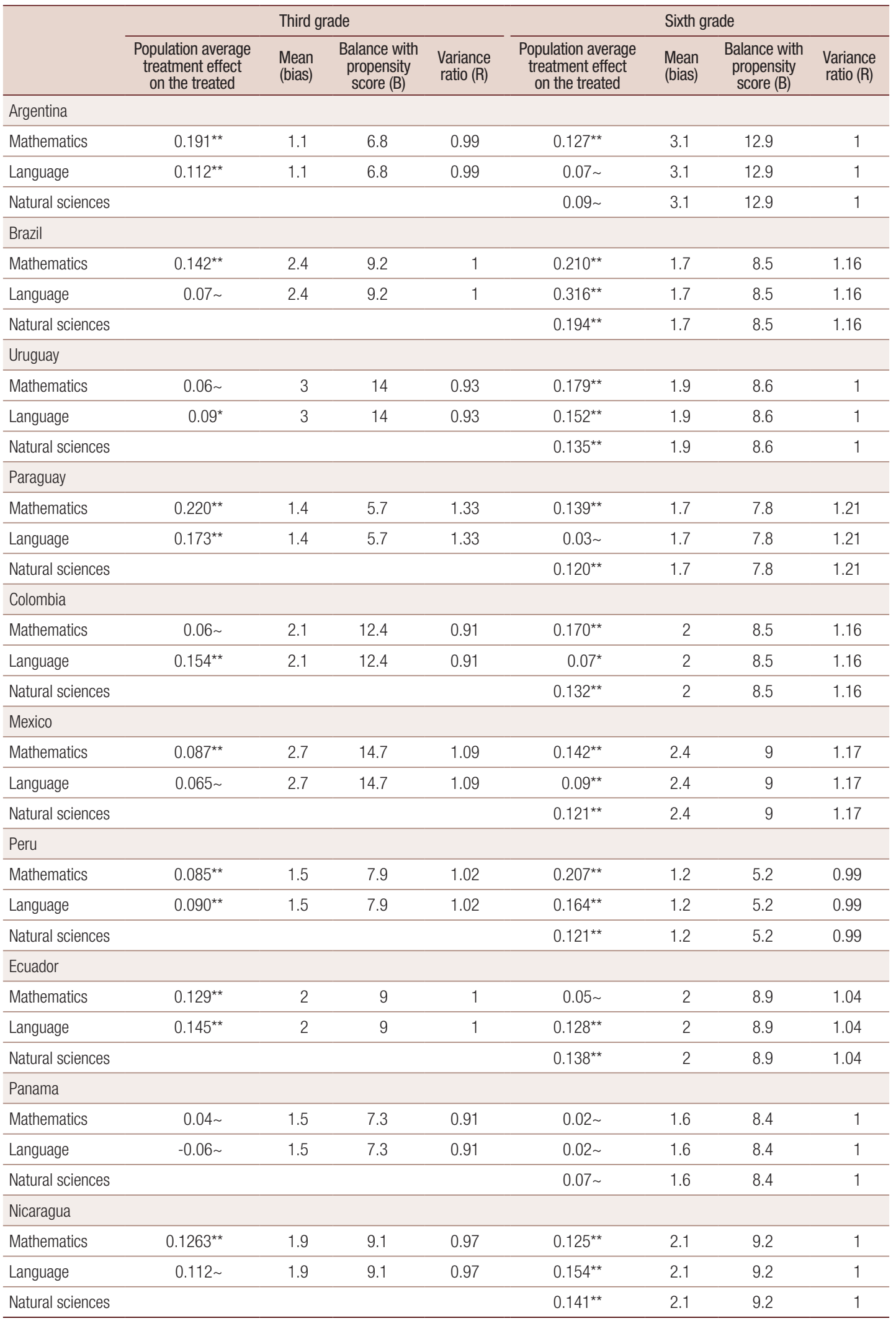


Table 5 (concluded)

\begin{tabular}{|c|c|c|c|c|c|c|c|c|}
\hline & & Third g & & & & Sixth $g$ & & \\
\hline & $\begin{array}{l}\text { Population average } \\
\text { treatment effect } \\
\text { on the treated }\end{array}$ & $\begin{array}{l}\text { Mean } \\
\text { (bias) }\end{array}$ & $\begin{array}{l}\text { Balance with } \\
\text { propensity } \\
\text { score (B) }\end{array}$ & $\begin{array}{l}\text { Variance } \\
\text { ratio }(\mathrm{R})\end{array}$ & $\begin{array}{l}\text { Population average } \\
\text { treatment effect } \\
\text { on the treated }\end{array}$ & $\begin{array}{l}\text { Mean } \\
\text { (bias) }\end{array}$ & $\begin{array}{l}\text { Balance with } \\
\text { propensity } \\
\text { score (B) }\end{array}$ & $\begin{array}{l}\text { Variance } \\
\text { ratio }(\mathrm{R})\end{array}$ \\
\hline Guatemala & & & & & & & & \\
\hline Mathematics & $0.07 \sim$ & 5 & 24.4 & 0.76 & $0.116^{*}$ & 2.5 & 11.6 & 0.92 \\
\hline Language & $0.214^{\star *}$ & 5 & 24.4 & 0.76 & $0.05 \sim$ & 2.5 & 11.6 & 0.92 \\
\hline Natural sciences & & & & & $0.109^{\star *}$ & 2.5 & 11.6 & 0.92 \\
\hline Honduras & & & & & & & & \\
\hline Mathematics & $0.223 \sim$ & 2.1 & 8.7 & 1.05 & $0.179^{\star *}$ & 2 & 10.3 & 1.3 \\
\hline Language & $0.189 \sim$ & 2.1 & 8.7 & 1.05 & $0.143^{*}$ & 2 & 10.3 & 1.3 \\
\hline Natural sciences & & & & & $0.09 \sim$ & 2 & 10.3 & 1.3 \\
\hline Dominican Republ & & & & & & & & \\
\hline Mathematics & $0.08 \sim$ & 1.1 & 5.9 & 1.09 & $0.167^{\star \star}$ & 1 & 5.4 & 1.19 \\
\hline Language & $0.105^{\star}$ & 1.1 & 5.9 & 1.09 & $0.69 \sim$ & 1 & 5.4 & 1.19 \\
\hline Natural sciences & & & & & $0.108^{*}$ & 1 & 5.4 & 1.19 \\
\hline Chile & & & & & & & & \\
\hline Mathematics & $0.104^{\star *}$ & 2.1 & 10.4 & 1.1 & $0.124^{\star *}$ & 1.4 & 6.1 & 1.07 \\
\hline Language & $0.101^{\star *}$ & 2.1 & 10.4 & 1.1 & $0.04 \sim$ & 1.4 & 6.1 & 1.07 \\
\hline Natural sciences & & & & & $0.03 \sim$ & 1.4 & 6.1 & 1.07 \\
\hline
\end{tabular}

Source: Prepared by the authors.

Note: ${ }^{* \star}$ Significant at 5\%; * Significant at 10\%; Not significant; Bootstrap standard errors (100 replications).

In the short term (third grade) a positive effect was found for most countries in both mathematics and reading, but there are some notable differences in the effect size. For countries such as Honduras and Paraguay, the effect of preschool attendance on mathematics varies between 0.25 and 0.33 of a standard deviation. In terms of scores, the effect size is equivalent to between 24 and 31 points on the test (sample average treatment effect on the treated), however the effects are the same when the population average treatment effect on the treated is considered and are not significant for Honduras. In the remaining countries, the estimated effect (the average treatment effect on the treated and population average treatment effect on the treated) is generally between 0.08 and 0.2 standard deviations, which is within the expected values in other estimates found in the aforementioned literature. With the exception of the Dominican Republic, Ecuador and Guatemala (sample average treatment effect on the treated) - and also of Colombia and Uruguay when the population average treatment effect on the treated is considered-, the effect size is smaller for the reading tests in the vast majority of countries. This characteristic would seem to suggest that mathematics learning in schools generate a greater advantage than language-related activities. This is not surprising when one considers that language acquisition begins at a very early age in the home.

Analysis of results for sixth grade, which include a natural sciences assessment, reveals some particularities. First, in the vast majority of countries, the effect of preschool on mathematics outcomes is more pronounced (sample average treatment effect on the treated and population average treatment effect on the treated), and only in Argentina, Ecuador, Honduras and Paraguay does the coefficient size of the population average treatment effect on the treated decrease. The opposite appears to be true for reading in many countries. Thus, in the countries of the Southern Cone (Argentina, Chile and Paraguay), the effect of preschool attendance on the TERCE test score decreases, as seen in the sample average treatment effect on the treated and population average treatment effect on the treated, while in more populous countries like Brazil, Colombia and Mexico the causal effect size. Second, the magnitude of 
the changes is heterogeneous. For example, the population average effect of treatment on the treated for reading goes from 0.07 (non-significant) in third grade to 0.31 in sixth grade in Brazil, while in Paraguay it decreases from 0.173 in third grade to 0.03 (non-significant) in sixth grade.

Regardless of whether there is an increase or decrease in the medium-term effect of preschool attendance on test results, the effect sizes for Brazil, the Dominican Republic, Nicaragua and Paraguay vary markedly. Third, although the largest effect size continues to be in mathematics, the results in natural sciences is noteworthy. It could often be said that experimentation, guided learning and learning to follow instructions at an early young age stimulates the acquisition of science and scientific skills, hence preschool attendance has an effect ranging from 0.07 to 0.2 standard deviations in the sixth-grade TERCE score (10 of the 14 countries considered have a coefficient greater than 0.10 standard deviations in the average effect of treatment on the treatment of the target population).

The above results substantiate the importance of continuing efforts to increase preschool education coverage, since, in addition to the direct benefits mentioned for pupils, there is also evidence of indirect benefits on equity, mothers' labour market participation, and health.

\section{Conclusions}

There are considerable differences in access to preschool education in Latin America today, and these differences are more pronounced among pupils in urban and rural areas.

The results obtained from the propensity score matching on the TERCE test seem to indicate that there are positive effects of attending preschool and that these effects persist up to six years after preschool. This outcome has important education policy implications because it illustrates the need to reduce the inequality of opportunities at the beginning of the education cycle by making the necessary investments to ensure that children attend school at a younger age.

Notwithstanding the above, the results vary between countries, subjects and period for the TERCE test. This implies that the evidence does not support an upward or downward trend for all the countries studied. Domestic policies may help to reduce inequalities in access and thus improve the cognitive and non-cognitive outcomes among the most vulnerable pupils. While there are very diverse institutional variables, it can be affirmed that, on average, the general trend in mathematics differs from that in reading. Preschool attendance was also found to have a positive effect on natural sciences and, after controlling for covariates mentioned above, the size of the effect was not insignificant.

These findings provide important evidence to support continuing efforts to achieve universal coverage, which enhance development potential by providing additional education options for children and by increasing opportunities for mothers to participate in the labour market. It must be borne in mind that the younger children are enrolled in school, the more likely they are to have better cognitive and non-cognitive achievements. These are very important if vulnerable communities are to achieve other health and nutrition goals.

The resulting evidence suggests that governments must be encouraged to intensify and sustain efforts in the area of early childhood education, making available the necessary resources not only to expand coverage, but also to improve the quality of these programmes. Given the return on such investments, it is important to monitor both quality and coverage in rural areas to reduce the inequality of access in Latin America. Only thus can it be said that preschool education is guaranteeing children's rights. 


\section{Bibliography}

Abadie, A. and G. Imbens (2005), "On the failure of the bootstrap for matching estimators" [online] http:// www.princeton.edu/ erp/Econometrics/Old\%20Pdfs/Abadie.pdf.

Araujo, M., M. Dormal and N. Schady (2017), "Child care quality and child development", IDB Working Paper, No. 779, Washington, D.C., Inter-American Development Bank (IDB).

Behrman, J., Y. Cheng and P. Todd (2004), "Evaluating preschool programs when length of exposure to the program varies: a nonparametric approach", The Review of Economics and Statistics, vol. 86, No. 1, Cambridge, MIT Press.

Berlinski, S., S. Galiani and M. Manacorda (2008), "Giving children a better start: preschool attendance and school-age profiles", Journal of Public Economics, vol. 92, No. 5-6, Amsterdam, Elsevier.

Berlinski, S. and N. Schady (eds.) (2015), The Early Years: Child Well-being and the Role of Public Policy, Washington, D.C., Inter-American Development Bank (IDB).

Bernal, R. and A. Camacho (2012), "La política de primera infancia en el contexto de la equidad y movilidad social en Colombia", Documentos CEDE, No. 33, Bogota, University of Los Andes.

Bernal, R. and others (2015), "The effects of the transition from home-based childcare to center-based childcare in Colombia", Bogota, University of Los Andes, unpublished.

_ (2012), Evaluación de impacto del Programa Jardines Sociales/Centros de Desarrollo Infantil. Informe final de impacto, Bogota, University of Los Andes.

Black, D. (2015), "Matching as a regression estimator", IZA World of Labor, No. 186, Bonn.

Brookhart, M. and others (2006), "Variable selection for propensity score models", American Journal of Epidemiology, vol. 163, No. 12, Oxford, Oxford University Press.

Caliendo, M. and S. Kopeinig (2008), "Some practical guidance for the implementation of propensity score matching", Journal of Economic Surveys, vol. 22, No. 1, Hoboken, Wiley.

Cascio, E. (2015), "The promises and pitfalls of universal early education”, IZA World of Labor, No. 116, Bonn.

Cohen, J. (1992), "A power primer", Psychological Bulletin, vol. 112, No. 1, Washington, D.C., American Psychological Association.

(1988), Statistical Power Analysis for the Behavioral Sciences, Hillsdale, Lawrence Erlbaum Associates.

DuGoff, E., M. Schuler and E. Stuart (2014), "Generalizing observational study results: applying propensity score methods to complex surveys", Health Services Research, vol. 49, No. 1, Hoboken, Wiley.

Gamboa, L. and N. Krüger (2016), "Does the contribution made by early education to later academic achievement differ in Latin America?: PISA 2009-2012", CEPAL Review, No. 118 (LC/G-2676-P), Santiago, Economic Commission for Latin America and the Caribbean (ECLAC).

Heckman, J., R. Pinto and P. Savelyev (2013), "Understanding the mechanisms through which an influential early childhood program boosted adult outcomes", American Economic Review, vol. 103, No. 6, Nashville, American Economic Association.

Heckman, J. and R. Robb (1986), "Alternative methods for solving the problem of selection bias in evaluating the impact of treatments on outcomes", Drawing Inferences from Self-Selected Samples, H. Wainer (ed.), New York, Springer.

Loeb, S. and others (2007), "How much is too much? The influence of preschool centers on children's social and cognitive development", Economics of Education Review, vol. 26, No. 1, Amsterdam, Elsevier.

Magnuson, K., C. Ruhm and J. Waldfogel (2007a), "Does prekindergarten improve school preparation and performance?", Economics of Education Review, vol. 26, No. 1, Amsterdam, Elsevier.

(2007b), "The persistence of preschool effects: do subsequent classroom experience matter?", Early Childhood Research Quarterly, vol. 22, No. 1, Amsterdam, Elsevier.

Mateo, M. and L. Rodríguez-Chamussy (2013), "Childcare and women's labor participation: evidence for Latin America and the Caribbean", IDB Technical Note, No. 586, Washington, D.C., Inter-American Development Bank (IDB).

MINEDUC (Ministry of Education of Chile) (2014), "Estado del arte de la educación parvularia en Chile", Santiago.

Nores, M. and W. Barnett (2010), "Benefits of early childhood interventions across the world: (under) investing in the very young", Economics of Education Review, vol. 29, No. 2, Amsterdam, Elsevier.

Rosenbaum, P. (2002), Observational Studies, New York, Springer.

Rosenbaum, P. and D. Rubin (1983), "The central role of the propensity score in observational studies for causal effects", Biometrika, vol. 70, No. 1, Oxford, Oxford University Press. 
Rubin, D. (2001), "Using propensity scores to help design observational studies: application to the tobacco litigation", Health Services and Outcomes Research Methodology, vol. 2, No. 3-4, New York, Springer.

Schady, N. and others (2015), "Wealth gradients in early childhood cognitive development in five Latin American countries", Journal of Human Resources, vol. 50, No. 2, Madison, University of Wisconsin Press.

Shah, H. and others (2017), "One or two years of participation: is dosage of an enhanced publicly funded preschool program associated with the academic and executive function skills of low-income children in early elementary school?", Early Childhood Research Quarterly, vol. 40, Amsterdam, Elsevier.

Shonkoff, J. and D. Phillips (2000), From Neurons to Neighborhoods: The Science of Early Childhood Development, Washington, D.C., National Academy Press.

Skibbe, L. and others (2011), "Schooling effects on preschoolers' self-regulation, early literacy, and language growth", Early Childhood Research Quarterly, vol. 26, No. 1, Amsterdam, Elsevier.

SOPLA (Programa Regional sobre Políticas Sociales) (2014), Los desafíos de educación preescolar, básica y media en América Latina, Santiago, Konrad Adenauer Stiftung/Programa Regional sobre Políticas Sociales (SOPLA).

Stuart, E. (2010), "Matching methods for causal inference: a review and look forward", Statistical Science, vol. 25, No. 1, Beachwood, Institute of Mathematical Statistics (IMS).

Temple, J. and A. Reynolds (2007), "Benefits and costs of investments in preschool education: evidence from the Child-Parent Centers and related programs", Economics of Education Review, vol. 26, No. 1, Amsterdam, Elsevier.

UNESCO (United Nations Educational, Scientific and Cultural Organization) (2016), Reporte técnico. Tercer Estudio Regional Comparativo y Explicativo (TERCE), Santiago. (2014), EFA Global Monitoring Report 2013/4. Teaching and Learning: Achieving Quality for All, Paris. (2013), Situación educativa de América Latina y el Caribe: hacia una educación para todos 2015, Santiago. (2008), Indicadores de la educación de la primera infancia en América Latina: propuesta y experiencias piloto, Santiago.

Wagstaff, A. (2007), "Health insurance for the poor: initial impacts of Vietnam's Health Care Fund for the Poor", Impact Evaluation Series, No. 11, Washington, D.C., World Bank.

Wen, X. and others (2012), "Are two years better than one year? A propensity score analysis of the impact of Head Start program duration on children's school performance in kindergarten”, Early Childhood Research Quarterly, vol. 27, No. 4, Amsterdam, Elsevier. 


\section{Annex A1}

Table A1.1

Effective sample from the Third Regional Comparative and Explanatory Study (TERCE)

\begin{tabular}{|c|c|c|c|c|c|c|}
\hline & \multicolumn{2}{|c|}{ Reading } & \multicolumn{2}{|c|}{ Mathematics } & \multicolumn{2}{|c|}{ Natural sciences } \\
\hline & Third grade & Sixth grade & Third grade & Sixth grade & Third grade & Sixth grade \\
\hline Argentina & 3655 & 3658 & 3751 & 3639 & 3663 & 3632 \\
\hline Brazil & 3254 & 2900 & 3343 & 2983 & 2986 & 3908 \\
\hline Chile & 4751 & 5056 & 4709 & 5044 & 5029 & 4754 \\
\hline Colombia & 4018 & 4343 & 3975 & 4308 & 4325 & 4028 \\
\hline Costa Rica & 3427 & 3490 & 3428 & 3520 & 3520 & 3436 \\
\hline Ecuador & 4631 & 4842 & 4642 & 4818 & 4820 & 4621 \\
\hline Guatemala & 4060 & 3891 & 4282 & 4056 & 4070 & 4112 \\
\hline Honduras & 3743 & 3788 & 3870 & 3880 & 3886 & 3651 \\
\hline Mexico & 3465 & 3554 & 3543 & 3618 & 3622 & 3456 \\
\hline Nicaragua & 3513 & 3470 & 3810 & 3726 & 3741 & 3537 \\
\hline Paraguay & 3123 & 3175 & 3271 & 3222 & 3231 & 3274 \\
\hline Peru & 4946 & 4739 & 5038 & 4789 & 4801 & 5003 \\
\hline Dominican Republic & 3504 & 3588 & 3757 & 3661 & 3669 & 3652 \\
\hline Uruguay & 2663 & 2799 & 2728 & 2799 & 2803 & 2672 \\
\hline Total & 56036 & 56779 & 57561 & 57476 & 54055 & 56500 \\
\hline
\end{tabular}

Source: United Nations Educational, Scientific and Cultural Organization (UNESCO), TERCE: Learning Achievements, Executive Summary, Santiago, 2016.

Table A1.2

Propensity score matching results: sample average treatment effect on the treated

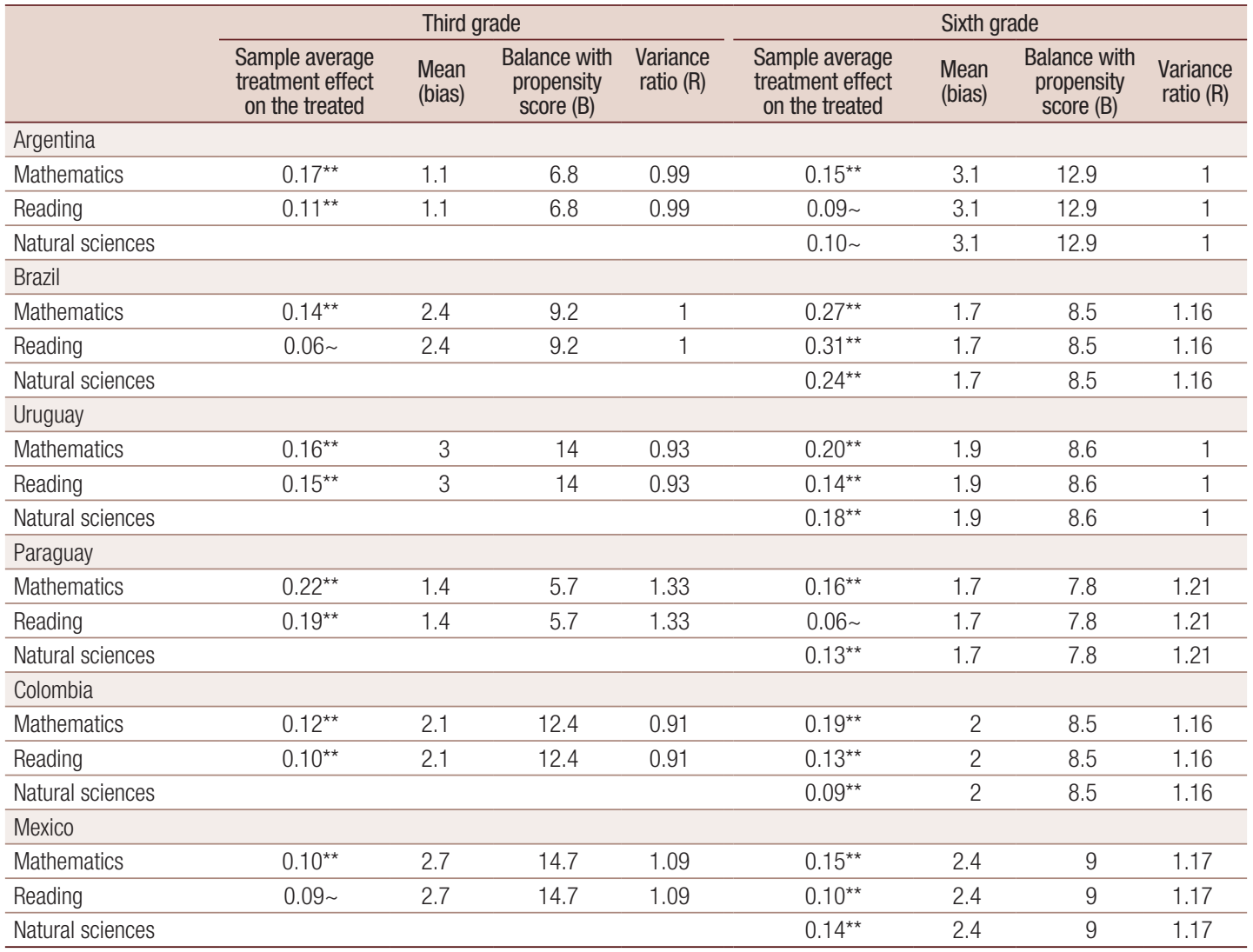


Table A1.2 (concluded)

\begin{tabular}{|c|c|c|c|c|c|c|c|c|}
\hline & \multicolumn{4}{|c|}{ Third grade } & \multicolumn{4}{|c|}{ Sixth grade } \\
\hline & $\begin{array}{c}\text { Sample average } \\
\text { treatment effect } \\
\text { on the treated }\end{array}$ & $\begin{array}{l}\text { Mean } \\
\text { (bias) }\end{array}$ & $\begin{array}{l}\text { Balance with } \\
\text { propensity } \\
\text { score (B) }\end{array}$ & $\begin{array}{l}\text { Variance } \\
\text { ratio (R) }\end{array}$ & $\begin{array}{c}\text { Sample average } \\
\text { treatment effect } \\
\text { on the treated }\end{array}$ & $\begin{array}{l}\text { Mean } \\
\text { (bias) }\end{array}$ & $\begin{array}{l}\text { Balance with } \\
\text { propensity } \\
\text { score (B) }\end{array}$ & $\begin{array}{l}\text { Variance } \\
\text { ratio }(\mathrm{R})\end{array}$ \\
\hline \multicolumn{9}{|l|}{ Peru } \\
\hline Mathematics & $0.13^{\star *}$ & 1.5 & 7.9 & 1.02 & $0.21^{\star *}$ & 1.2 & 5.2 & 0.99 \\
\hline Reading & $0.13^{\star \star}$ & 1.5 & 7.9 & 1.02 & $0.15^{\star \star}$ & 1.2 & 5.2 & 0.99 \\
\hline Natural sciences & & & & & $0.11^{\star \star}$ & 1.2 & 5.2 & 0.99 \\
\hline \multicolumn{9}{|l|}{ Ecuador } \\
\hline Mathematics & $0.12^{\star *}$ & 2 & 9 & 1 & $0.06 \sim$ & 2 & 8.9 & 1.04 \\
\hline Reading & $0.14^{\star \star}$ & 2 & 9 & 1 & $0.11^{\star \star}$ & 2 & 8.9 & 1.04 \\
\hline Natural sciences & & & & & $0.11 \sim$ & 2 & 8.9 & 1.04 \\
\hline \multicolumn{9}{|l|}{ Nicaragua } \\
\hline Mathematics & $0.16^{\star \star}$ & 1.9 & 9.1 & 0.97 & $0.19^{\star \star}$ & 2.1 & 9.2 & 1 \\
\hline Reading & $0.08 \sim$ & 1.9 & 9.1 & 0.97 & $0.17^{\star \star}$ & 2.1 & 9.2 & 1 \\
\hline Natural sciences & & & & & $0.22^{\star *}$ & 2.1 & 9.2 & 1 \\
\hline \multicolumn{9}{|l|}{ Guatemala } \\
\hline Mathematics & $0.08 \sim$ & 5 & 24.4 & 0.76 & $0.14^{\star \star}$ & 2.5 & 11.6 & 0.92 \\
\hline Reading & $0.20^{* \star}$ & 5 & 24.4 & 0.76 & $0.13^{\star *}$ & 2.5 & 11.6 & 0.92 \\
\hline Natural sciences & & & & & $0.15^{\star \star}$ & 2.5 & 11.6 & 0.92 \\
\hline \multicolumn{9}{|l|}{ Honduras } \\
\hline Mathematics & $0.34^{\star \star}$ & 2.1 & 8.7 & 1.05 & $0.29^{\star \star}$ & 2 & 10.3 & 1.3 \\
\hline Reading & $0.23^{\star *}$ & 2.1 & 8.7 & 1.05 & $0.28^{\star \star}$ & 2 & 10.3 & 1.3 \\
\hline Natural sciences & & & & & $0.29^{\star *}$ & 2 & 10.3 & 1.3 \\
\hline \multicolumn{9}{|c|}{ Dominican Republic } \\
\hline Mathematics & $0.11 \sim$ & 1.1 & 5.9 & 1.09 & $0.18^{\star \star}$ & 1 & 5.4 & 1.19 \\
\hline Reading & $0.20^{\star *}$ & 1.1 & 5.9 & 1.09 & $0.11 \sim$ & 1 & 5.4 & 1.19 \\
\hline Natural sciences & & & & & $0.14^{\star *}$ & 1 & 5.4 & 1.19 \\
\hline \multicolumn{9}{|l|}{ Chile } \\
\hline Mathematics & $0.14^{* \star}$ & 2.1 & 10.4 & 1.1 & $0.11^{\star \star}$ & 1.4 & 6.1 & 1.07 \\
\hline Reading & $0.11^{* \star}$ & 2.1 & 10.4 & 1.1 & $0.05 \sim$ & 1.4 & 6.1 & 1.07 \\
\hline Natural sciences & & & & & $0.04 \sim$ & 1.4 & 6.1 & 1.07 \\
\hline
\end{tabular}

Source: Prepared by the authors, based on data from the Third Regional Comparative and Explanatory Study (TERCE).

Note: ${ }^{* *}$ significant at 5\%, ${ }^{*}$ Significant at 10\%, Not significant.

Table A1.3

Cohen's $d$ effect size in the sample preschool attendance-no preschool attendance after propensity score matching

\begin{tabular}{|c|c|c|c|c|c|}
\hline \multirow{2}{*}{ Country } & \multicolumn{2}{|c|}{ Mathematics } & \multicolumn{2}{|c|}{ Reading } & \multirow{2}{*}{$\begin{array}{c}\text { Natural sciences } \\
\text { Sixth grade }\end{array}$} \\
\hline & Third grade & Sixth grade & Third grade & Sixth grade & \\
\hline Argentina & 0.39 & 0.43 & 0.42 & 0.41 & 0.30 \\
\hline Brazil & 0.43 & 0.57 & 0.40 & 0.70 & 0.57 \\
\hline Uruguay & 0.57 & 0.55 & 0.47 & 0.51 & 0.53 \\
\hline Paraguay & 0.59 & 0.63 & 0.69 & 0.74 & 0.65 \\
\hline Colombia & 0.66 & 0.63 & 0.68 & 0.66 & 0.49 \\
\hline Mexico & 0.48 & 0.43 & 0.47 & 0.47 & 0.44 \\
\hline Peru & 0.55 & 0.61 & 0.55 & 0.65 & 0.52 \\
\hline Ecuador & 0.33 & 0.38 & 0.39 & 0.52 & 0.42 \\
\hline Nicaragua & 0.46 & 0.51 & 0.46 & 0.55 & 0.53 \\
\hline Guatemala & 0.74 & 0.56 & 0.73 & 0.60 & 0.60 \\
\hline Honduras & 0.76 & 0.71 & 0.73 & 0.75 & 0.67 \\
\hline Dominican Republic & 0.48 & 0.41 & 0.55 & 0.43 & 0.43 \\
\hline Chile & 0.41 & 0.38 & 0.38 & 0.33 & 0.35 \\
\hline
\end{tabular}

Source: Prepared by the authors, based on data from the Third Regional Comparative and Explanatory Study (TERCE).

Note: Very small $(d \leqq 0.20)$, small $(0.20<d \leqq 0.50)$, moderate $(0.50<d \leqq 0.80)$ and large $(>0.80)$. Sample after propensity score matching, common support. 
Table A1.4

Pupil distribution, by socioeconomic characteristics

(Proportion of the sample)

\begin{tabular}{|c|c|c|c|c|c|c|c|c|c|c|c|c|c|c|c|}
\hline & ARG & BRA & CHL & $\mathrm{COL}$ & CRI & DOM & ECU & GTM & HND & MEX & NIC & PRY & PER & URY & Total \\
\hline & \multicolumn{15}{|c|}{ Sixth grade } \\
\hline \multicolumn{16}{|l|}{ Pupil age } \\
\hline 11 years & 0.15 & 0.00 & 0.06 & 0.12 & 0.00 & 0.20 & 0.32 & 0.02 & 0.07 & 0.02 & 0.14 & 0.12 & 0.28 & 0.03 & 0.11 \\
\hline 12 years & 0.68 & 0.27 & 0.76 & 0.49 & 0.52 & 0.43 & 0.54 & 0.23 & 0.5 & 0.72 & 0.46 & 0.62 & 0.51 & 0.77 & 0.55 \\
\hline $13-15$ years & 0.17 & 0.73 & 0.18 & 0.39 & 0.48 & 0.37 & 0.14 & 0.75 & 0.43 & 0.26 & 0.40 & 0.25 & 0.21 & 0.20 & 0.34 \\
\hline Girls & 0.49 & 0.52 & 0.51 & 0.5 & 0.5 & 0.51 & 0.47 & 0.49 & 0.5 & 0.5 & 0.54 & 0.51 & 0.5 & 0.52 & 0.5 \\
\hline Rural school & 0.34 & 0.18 & 0.22 & 0.38 & 0.09 & 0.35 & 0.27 & 0.66 & 0.55 & 0.27 & 0.51 & 0.39 & 0.31 & 0.14 & 0.34 \\
\hline Urban-public school & 0.42 & 0.5 & 0.20 & 0.20 & 0.71 & 0.44 & 0.48 & 0.25 & 0.12 & 0.47 & 0.27 & 0.25 & 0.37 & 0.67 & 0.37 \\
\hline \multicolumn{16}{|c|}{ Mother's level of education } \\
\hline No schooling & 0.03 & 0.15 & 0.03 & 0.03 & 0.06 & 0.07 & 0.05 & 0.18 & 0.13 & 0.07 & 0.09 & 0.03 & 0.07 & 0.01 & 0.07 \\
\hline [ISCED-P 1-2] & 0.40 & 0.31 & 0.21 & 0.29 & 0.42 & 0.31 & 0.45 & 0.52 & 0.45 & 0.51 & 0.39 & 0.38 & 0.32 & 0.34 & 0.39 \\
\hline [ISCED-P 3] & 0.34 & 0.37 & 0.33 & 0.34 & 0.25 & 0.29 & 0.31 & 0.23 & 0.19 & 0.17 & 0.31 & 0.30 & 0.32 & 0.45 & 0.29 \\
\hline [ISCED-P 4-5] & 0.14 & 0.03 & 0.19 & 0.17 & 0.15 & 0.08 & 0.03 & 0.04 & 0.05 & 0.05 & 0.06 & 0.11 & 0.16 & 0.09 & 0.10 \\
\hline [ISCED-P 6-8] & 0.09 & 0.14 & 0.24 & 0.17 & 0.12 & 0.26 & 0.16 & 0.03 & 0.19 & 0.20 & 0.15 & 0.18 & 0.12 & 0.11 & 0.16 \\
\hline \multicolumn{16}{|c|}{ Father's level of education } \\
\hline No schooling & 0.03 & 0.19 & 0.03 & 0.04 & 0.06 & 0.07 & 0.06 & 0.12 & 0.14 & 0.08 & 0.11 & 0.03 & 0.03 & 0.02 & 0.06 \\
\hline [ISCED-P 1-2] & 0.48 & 0.36 & 0.22 & 0.33 & 0.44 & 0.39 & 0.44 & 0.52 & 0.46 & 0.49 & 0.39 & 0.37 & 0.30 & 0.43 & 0.40 \\
\hline [ISCED-P 3] & 0.33 & 0.31 & 0.32 & 0.34 & 0.23 & 0.27 & 0 & 0.26 & 0.16 & 6 & 0.29 & 0.31 & 36 & 0.41 & 0.28 \\
\hline [ISCED-P 4-5] & 0.07 & 0.02 & 0.14 & 0.13 & 0.14 & 0.10 & 0.05 & 0.04 & 0.06 & 0.04 & 0.06 & 0.11 & 0.16 & 0.06 & 0.09 \\
\hline [ISCED-P 6-8] & 0.08 & 0.12 & 0.29 & 0.17 & 0.12 & 0.17 & 0.15 & 0.05 & 0.18 & 0.23 & 0.16 & 0.17 & 0.15 & 0.08 & 0.16 \\
\hline & \multicolumn{15}{|c|}{ Third grade } \\
\hline 8 years & 0.18 & 0.00 & 0.05 & 0.13 & 0.00 & 0.18 & 0.33 & 0.01 & 0.09 & 0.03 & 0.16 & 0.17 & 0.22 & 0.03 & 0.11 \\
\hline 9 years & 0.71 & 0.17 & 0.77 & 0.60 & 0.51 & 0.5 & 0.57 & 0.27 & 0.55 & 0.86 & 0.47 & 0.61 & 0.61 & 0.81 & 0.60 \\
\hline $10-11$ years & 0.11 & 0.83 & 0.18 & 0.27 & 0.49 & 0.32 & 0.10 & 0.72 & 0.36 & 0.11 & 0.37 & 0.22 & 0.17 & 0.16 & 0.28 \\
\hline Girls & 0.48 & 0.5 & 0.5 & 0.52 & 0.48 & 0.51 & 0.46 & 0.49 & 0.5 & 0.51 & 0.5 & 0.48 & 0.48 & 0.51 & 0.49 \\
\hline Rural school & 0.34 & 0.22 & 0.22 & 0.35 & 0.08 & 0.35 & 0.27 & 0.64 & 0.57 & 0.28 & 0.56 & 0.40 & 0.33 & 0.15 & 0.35 \\
\hline Urban-public school & 0.40 & 0.46 & 0.18 & 0.22 & 0.72 & 0.38 & 0.48 & 0.25 & 0.11 & 0.44 & 0.22 & 0.23 & 0.35 & 0.64 & 0.36 \\
\hline \multicolumn{16}{|c|}{ Mother's level of education } \\
\hline No schooling & 0.02 & 0.14 & 0.02 & 0.03 & 0.06 & 0.08 & 0.05 & 0.16 & 0.13 & 0.06 & 0.10 & 0.04 & 0.08 & 0.01 & 0.06 \\
\hline [ISCED-P 1-2] & 0.37 & 0.30 & 0.18 & 0.24 & 0.40 & 0.31 & 0.43 & 0.52 & 0.42 & 0.47 & 0.35 & 0.37 & 0.32 & 0.32 & 0.3 \\
\hline [ISCED-P 3] & 0.36 & 0.38 & 0.34 & 0.33 & 0.26 & 0.28 & 0.32 & 0.24 & 0.22 & 0.18 & 0.31 & 0.28 & 0.33 & 0.44 & 0.30 \\
\hline [ISCED-P 4-5] & 0.13 & 0.02 & 0.20 & 0.19 & 0.15 & 0.06 & 0.04 & 0.04 & 0.05 & 0.05 & 0.07 & 0.11 & 0.17 & 0.11 & 0.10 \\
\hline [ISCED-P 6-8] & 0.11 & 0.16 & 0.25 & 0.20 & 0.13 & 0.27 & 0.15 & 0.04 & 0.19 & 0.23 & 0.17 & 0.20 & 0.11 & 0.11 & 0.17 \\
\hline \multicolumn{16}{|c|}{ Father's level of education } \\
\hline No schooling & 0.04 & 0.18 & 0.03 & 0.04 & 0.07 & 0.09 & 0.06 & 0.13 & 0.14 & 0.07 & 0.12 & 0.04 & 0.04 & 0.02 & 0.07 \\
\hline [ISCED-P 1-2] & 0.46 & 0.35 & 0.21 & 0.29 & 0.44 & 0.38 & 0.42 & 0.51 & 0.45 & 0.48 & 0.39 & 0.35 & 0.29 & 0.39 & 0.39 \\
\hline [ISCED-P 3] & 0.35 & 0.33 & 0.33 & 0.34 & 0.23 & 0.27 & 0.32 & 0.27 & 0.18 & 0.17 & 0.26 & 0.32 & 0.38 & 0.44 & 0.29 \\
\hline [ISCED-P 4-5] & 0.07 & 0.02 & 0.15 & 0.15 & 0.14 & 0.08 & 0.06 & 0.05 & 0.07 & 0.05 & 0.07 & 0.11 & 0.16 & 0.06 & 0.09 \\
\hline [ISCED-P 6-8] & 0.09 & 0.11 & 0.28 & 0.17 & 0.12 & 0.18 & 0.14 & 0.05 & 0.15 & 0.23 & 0.16 & 0.17 & 0.13 & 0.09 & 0.16 \\
\hline
\end{tabular}

Source: Prepared by the authors, based on data from the Third Regional Comparative and Explanatory Study (TERCE).

Note: ISCED: International Standard Classification of Education. 
Table A1.5

Mean Third Regional Comparative and Explanatory Study (TERCE) reading and mathematics scores, sixth grade and third grade

\begin{tabular}{|c|c|c|c|c|c|c|c|c|c|c|c|c|c|c|c|}
\hline & $\mathrm{RG}$ & BRA & $\mathrm{HL}$ & $\mathrm{OL}$ & $\mathrm{RI}$ & $\mathrm{DOM}$ & ECU & GTM & HND & MEX & $\mathrm{NIC}$ & PRY & PER & URY & Total \\
\hline & \multicolumn{15}{|c|}{ Sixth grade } \\
\hline \multicolumn{16}{|l|}{ Readin } \\
\hline Girls & 3.2 & 1 & 5.7 & 3.1 & 9.1 & 51.8 & 3.7 & 684.8 & 702 & 2.5 & 76.4 & 82.8 & 98.8 & 50.2 & 22 \\
\hline \multicolumn{16}{|l|}{ Pupil age } \\
\hline 11 ye & 4.9 & 1.6 & 3.5 & 8.2 & 6.9 & 2.6 & 93.5 & 709.1 & 703 & 768 & 83.6 & 37.6 & 23.4 & 761.6 & 707.5 \\
\hline & 720 & 9.4 & 91.2 & 756.3 & 71.8 & 656.6 & 712 & 709.2 & 706.1 & 52.7 & 691.1 & 691.8 & 719.9 & 759.1 & 734.6 \\
\hline years & 68.1 & 52.8 & 776.2 & 725.4 & 67.9 & 629.5 & 664.7 & 694.1 & 701.4 & 747.2 & 658.6 & 634.2 & 643.2 & 680 & 711.9 \\
\hline $14-15 y$ & 644.1 & 681.8 & 724.2 & 685.2 & 714.8 & 602.5 & 634.8 & 656.4 & 661.5 & 670.3 & 632.7 & 608.4 & 606.8 & 652 & 652.4 \\
\hline 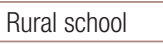 & 79.4 & 32.1 & 750.7 & 696.5 & 734 & 620.4 & 684.2 & 673 & 665.2 & 692.9 & 651.7 & 625.3 & 614.7 & 12.6 & 672.1 \\
\hline & 6.6 & 26.2 & 57.2 & 741 & 50.1 & 645.2 & 688.1 & 688.5 & 690.6 & 742.3 & 673.1 & 661.6 & 708.2 & 726.6 & 716.0 \\
\hline \multicolumn{16}{|l|}{ Father's level } \\
\hline- & 676.6 & 686.9 & 740.5 & 680.6 & 19.9 & 608.7 & 626.1 & 652.3 & 644.4 & 668.2 & 632.4 & 609.7 & 610.7 & 673.6 & 656.1 \\
\hline [ISC & 689.2 & 725.6 & 745.9 & 700 & 743.1 & 629.3 & 671.1 & 670 & 672.9 & 719.5 & 649.6 & 629.1 & 633.9 & 708.1 & 686.5 \\
\hline$[\mathrm{l}$ & 25.1 & 54.9 & 768.9 & 731 & 767.2 & 643.9 & 711 & 709.7 & 721.5 & 766.2 & 683.2 & 680.1 & 702.7 & 755.9 & 723.4 \\
\hline & 33.1 & 45.6 & 797.4 & 770.8 & 02.9 & 661.4 & 739.6 & 735.4 & 741.6 & 792.8 & 700.7 & 714.5 & 757.6 & 794.4 & 756.5 \\
\hline & 746.7 & 55.1 & 826.7 & 802.8 & 807.4 & 675.8 & 759 & 767.6 & 763.9 & 814.8 & 718.4 & 747.5 & 778.7 & 823.2 & 780.8 \\
\hline [ISCED-P 7-8] & 799.8 & 20.9 & 844.8 & 835.1 & 35.4 & 698.4 & 785.6 & 795.7 & 773.1 & 827.8 & 740.9 & 752.5 & 822.8 & 850.8 & 806.7 \\
\hline \multicolumn{16}{|l|}{ Mother's level of } \\
\hline & 676.2 & 82.7 & 742.8 & 666 & 2.7 & 607.1 & 630.7 & 58.2 & 647.4 & 664 & 633 & 606.6 & 607.2 & 667.8 & 654.7 \\
\hline The & 687.4 & 725.6 & 746.6 & 701.4 & 742.4 & 625.5 & 670 & 676 & 674.1 & 721.1 & 650.1 & 636.4 & 645.9 & 698 & 688.9 \\
\hline & 8.8 & 754.8 & 772.1 & 725.7 & 764.7 & 647.5 & 713.4 & 717.3 & 719.6 & 782.3 & 682.8 & 677.6 & 713.6 & 750.3 & 726.0 \\
\hline & 8.5 & 6.3 & 796.4 & 767 & 0.8 & 661.9 & 761 & 760.6 & 738.7 & 791 & 704.6 & 724.6 & 766 & 796.4 & 765.1 \\
\hline [ISC & 765.6 & 84.7 & 832.3 & 812.4 & 16.4 & 673.7 & 761.3 & 774.6 & 766.6 & 820.4 & 725.4 & 753.5 & 796.6 & 823.8 & 781.3 \\
\hline & 0.7 & 27.3 & 853 & 31.5 & 36.7 & 713.8 & 795.4 & 779.3 & 787.8 & 825.1 & 754.2 & 765.3 & 826.7 & 852.8 & 807.0 \\
\hline & \multicolumn{15}{|c|}{ Third grade reading } \\
\hline & 21.9 & 130.0 & 4.1 & 741.2 & 767.6 & 639.2 & 707.9 & 701 & 711.6 & 748.5 & 78 & 8.6 & 1.9 & 38.9 & 25. \\
\hline \multicolumn{16}{|l|}{ Pupil age } \\
\hline & 4.4 & 793 & 790.4 & 744.8 & 16.1 & 641.5 & 701.3 & 738.7 & 707.8 & 716.9 & 680.8 & 687.5 & 733.6 & 709.8 & 708.7 \\
\hline & 719.1 & 752 & 809.7 & 745.8 & 761.6 & 645.7 & 7.3 & 712.9 & 709.2 & 42 & 687.1 & 683.3 & 733.3 & 740.1 & 731.7 \\
\hline & 660 & 740.2 & 809.2 & 722 & 768.6 & 603.1 & 690.8 & 713.4 & 714 & 745.2 & 652.8 & 620.6 & 653.9 & 681 & 713.7 \\
\hline 1 & 640.3 & 675.3 & 763.6 & 671.7 & 704.5 & 606.7 & 656.3 & 663.4 & 675.8 & 662.5 & 644.8 & 627.8 & 645.4 & 660.5 & 658.6 \\
\hline & 691.2 & 688.3 & 773 & 689.1 & 27.5 & 614.4 & 691.4 & 680.6 & 675.7 & 693.9 & 651.1 & 632.1 & 647.8 & 709 & 677.0 \\
\hline $\begin{array}{l}\text { Urban-public } \\
\text { school }\end{array}$ & 0.1 & 5.8 & 1110.5 & 727 & 17.2 & 621.7 & 102.1 & 06.4 & 102.1 & 724.9 & 672.8 & 662.9 & 27.2 & 713.7 & 13. \\
\hline \multicolumn{16}{|c|}{ cation } \\
\hline & 684.4 & 675.3 & 8.8 & 663.4 & 4.8 & 605.6 & 660.8 & 658 & 662.1 & 663.2 & 644.7 & 601.9 & 645 & 680.1 & 661.2 \\
\hline [ISC & 691.1 & 717.1 & 769.8 & 696.4 & 741.1 & 616.2 & 683.9 & 678.6 & 684.1 & 711.1 & 652.9 & 637.3 & 661.2 & 695.7 & 688.4 \\
\hline & 721.4 & 745.8 & 793.9 & 728 & 756.4 & 625.2 & 716.9 & 729.2 & 724 & 755.9 & 671.9 & 674.1 & 721.2 & 741.6 & 724.2 \\
\hline & 746.8 & 768.6 & 817.8 & 762.9 & 794.7 & 657.9 & 750 & 754.1 & 730.4 & 763.4 & 704.3 & 695.6 & 774.8 & 774.5 & 758.6 \\
\hline [ISCE & 756.6 & 787.4 & 847.1 & 799.7 & 814.1 & 674 & 761.1 & 785.1 & 774.7 & 804.9 & 722.1 & 737.6 & 791.5 & 790.5 & 780.0 \\
\hline [ISCED-P 7-8] & 764.8 & 808.3 & 865.9 & 823.9 & 830.5 & 696.5 & 789 & 793.5 & 793.3 & 823.1 & 738.7 & 725.7 & 813.3 & 815.8 & 809.7 \\
\hline \multicolumn{16}{|l|}{ Mother's level of } \\
\hline No schooling & 678.7 & 667.1 & 758.2 & 664.1 & 702.2 & 604 & 663 & 660.1 & 662.7 & 659.9 & 641.7 & 604.7 & 637.3 & 704.7 & 658.6 \\
\hline & 684.5 & 708.6 & 767.6 & 686.5 & 738.4 & 611.2 & 682.7 & 688 & 684.3 & 712.8 & 656 & 638.5 & 669.3 & 688.8 & 688.9 \\
\hline & 720.5 & 742.3 & 795.8 & 728.2 & 766.5 & 627 & 718.9 & 737.7 & 738.1 & 764.1 & 670 & 669.3 & 735.2 & 738 & 728.6 \\
\hline [ISCED-P 4-5] & 732.4 & 752.5 & 817.8 & 766.5 & 790.2 & 651.5 & 752.3 & 783.3 & 739.5 & 767.6 & 697.3 & 707 & 781.1 & 768.9 & 765.7 \\
\hline [ISCED-P 6] & 750.7 & 793.4 & 852.1 & 796.1 & 810.5 & 671.2 & 760.8 & 798.1 & 765.7 & 802.4 & 733.3 & 740 & 809.4 & 795 & 777.5 \\
\hline [ISCED-P 7-8] & 771.3 & 803.5 & 873.6 & 823.7 & 825.6 & 719.4 & 791.9 & 803.7 & 777.9 & 834.6 & 745 & 755.8 & 835.7 & 799.5 & 811.9 \\
\hline
\end{tabular}


Table A1.5 (concluded)

\begin{tabular}{|c|c|c|c|c|c|c|c|c|c|c|c|c|c|c|c|}
\hline & ARG & BRA & $\mathrm{CHL}$ & $\mathrm{COL}$ & $\mathrm{CRI}$ & DOM & ECU & GTM & HND & MEX & $\mathrm{NIC}$ & PRY & PER & URY & otal \\
\hline & \multicolumn{15}{|c|}{ Sixth grade } \\
\hline \multicolumn{16}{|l|}{ Mathematics } \\
\hline Girls & 21.4 & 0.8 & 802.2 & 57.7 & 7.5 & 3.8 & 0.6 & 72.8 & 685.4 & 771 & 650.1 & 57.4 & 07.6 & 767.2 & 13.8 \\
\hline 11 years & 23.4 & 11.6 & 782.6 & 722.7 & 59.9 & 645.9 & 706.1 & 694.7 & 700.7 & 785.2 & 660.3 & 674.7 & 737 & 791.6 & 707.8 \\
\hline 12 years & 732 & 745 & 808.7 & 728.1 & 749.8 & 642.4 & 715.6 & 703.5 & 693.4 & 783.8 & 670.4 & 671.7 & 735.5 & 784.1 & 736.3 \\
\hline 13 years & 690.7 & 740.2 & 801.3 & 708.2 & 745.4 & 625.7 & 683.5 & 687.1 & 694.3 & 774.5 & 637.1 & 633 & 661.8 & 713.7 & 712.2 \\
\hline $14-15$ years & 73.6 & 677.5 & 732.7 & 676.7 & 696.6 & 611.8 & 662.5 & 657.7 & 663.3 & 688.4 & 636.1 & 620.2 & 643 & 679.1 & 657.6 \\
\hline Rural school & 00.9 & 81.5 & 762.2 & 682.4 & 07.5 & 620.4 & 691.9 & 671.6 & 666.1 & 732.6 & 640.8 & 633.5 & 644.8 & 750.8 & 677.2 \\
\hline $\begin{array}{l}\text { Urban } \\
\text { schoo }\end{array}$ & 21.7 & 3.1 & 767.2 & 710.4 & 729.7 & 635.8 & 700.7 & 679.9 & 667.1 & 772.3 & 651 & 644 & 721 & 754.2 & 719.0 \\
\hline \multicolumn{16}{|c|}{ Father's level of education } \\
\hline No schooling & 699.6 & 680 & 744.2 & 665.2 & 701.5 & 618.5 & 661.3 & 657.6 & 649.1 & 707.2 & 631.7 & 624.9 & 639.4 & 686.5 & 663.7 \\
\hline [ISCED-P 1-2] & 705.9 & 716.8 & 757.6 & 682.1 & 723.7 & 625.3 & 687 & 670.1 & 670.5 & 753.4 & 639.9 & 632.7 & 661.3 & 737.9 & 693.8 \\
\hline [ISCED-P 3] & 734.5 & 737.5 & 781.7 & 708.9 & 740.9 & 630.5 & 714.7 & 696.1 & 708.1 & 790.7 & 659.8 & 660.5 & 716.3 & 784.1 & 719.8 \\
\hline [ISCED-P 4-5] & 751 & 742.3 & 821.4 & 740.4 & 779.6 & 646.6 & 735.4 & 724.9 & 719 & 804.9 & 677.2 & 685 & 768.9 & 811.2 & 752.3 \\
\hline [ISCED-P 6] & 753.5 & 793.3 & 853.9 & 775.9 & 781.9 & 660.2 & 752 & 750.4 & 738.6 & 839.2 & 690.5 & 717.2 & 794.8 & 840.4 & 778.4 \\
\hline [ISCED-P 7-8] & 805.7 & 20.6 & 876.3 & 811.3 & 813.9 & 679.6 & 782.3 & 771.7 & 756.7 & 849.4 & 701.5 & 711.1 & 815.1 & 850.4 & 803.7 \\
\hline \multicolumn{16}{|c|}{ Mother's level of education } \\
\hline No schooling & 702.2 & 682.5 & 760.5 & 666.2 & 704.6 & 625.2 & 652.1 & 660.8 & 645 & 710.2 & 638.5 & 612.1 & 635 & 698.9 & 665.0 \\
\hline [ISCED & 701.6 & 711.9 & 756.4 & 682.7 & 723.9 & 623.8 & 688 & 672 & 672.1 & 754.8 & 640 & 638.6 & 671.9 & 727 & 696.0 \\
\hline [ISCED-P & 727.7 & 737.7 & 786.4 & 704.3 & 741 & 632.9 & 717.4 & 709.1 & 709 & 803 & 658.3 & 660.1 & 726 & 777.6 & 723.3 \\
\hline [ISCED-P 4-5 & 755.6 & 734.9 & 822.1 & 740.1 & 785.7 & 644.3 & 750 & 744.2 & 725.2 & 807 & 675.8 & 689.1 & 778.4 & 811.9 & 765.0 \\
\hline [ISCE] & 769.5 & 783.5 & 859.4 & 781 & 791 & 655.1 & 753.5 & 757.4 & 741.8 & 838.9 & 698.9 & 721.2 & 807.9 & 850.6 & 775.6 \\
\hline & 86.8 & 826.7 & 881.4 & 805.8 & 811.4 & 674 & 782.6 & 744.5 & 754.9 & 855.2 & 717.2 & 720.8 & 821.5 & 852.8 & 794.9 \\
\hline & \multicolumn{15}{|c|}{ Third grade } \\
\hline \multicolumn{16}{|l|}{ Mathematics } \\
\hline Girls & 5.8 & 747.9 & 796.7 & 714.6 & 754.4 & 629.3 & 701.6 & 689.1 & 706.5 & 758.3 & 668 & 672.1 & 712.3 & 748.9 & 719.2 \\
\hline \multicolumn{16}{|l|}{ Pupil age } \\
\hline 8 years & 731.9 & 753.4 & 782.1 & 723.5 & 699.7 & 636.8 & 697.8 & 708.1 & 709.8 & 730 & 675.5 & 676.2 & 730.9 & 727.8 & 705.5 \\
\hline ars & 729.9 & 770.8 & 799.1 & 727.4 & 759.1 & 636.8 & 709.1 & 705.8 & 707.7 & 759.8 & 680.1 & 683.7 & 731.1 & 757.6 & 732.2 \\
\hline 10 years & 674.4 & 759 & 795.3 & 708.4 & 764.8 & 602 & 688.4 & 708.7 & 713 & 746.9 & 653.8 & 638 & 655.5 & 685 & 714.9 \\
\hline 11 years & 648.3 & 691.3 & 739.4 & 660.8 & 708.5 & 606.3 & 665.4 & 656.8 & 681.9 & 681.9 & 652.6 & 623.5 & 645.3 & 657.4 & 659.7 \\
\hline Rural school & 704.1 & 707.7 & 761.3 & 675.7 & 724.3 & 610.8 & 687.5 & 675.8 & 681.3 & 717.8 & 656.3 & 649.5 & 647.8 & 726.9 & 679.9 \\
\hline $\begin{array}{l}\text { Urban-public } \\
\text { school }\end{array}$ & 2.3 & 730.6 & 766.2 & 706.8 & 745.2 & 613.8 & 698.7 & 698.8 & 691.3 & 745.4 & 663.8 & 654.3 & 724.8 & 726.1 & 716.0 \\
\hline \multicolumn{16}{|c|}{ Father's level of education } \\
\hline No & 679.1 & 694 & 742.9 & 652 & 707.8 & 608 & 673.6 & 647.5 & 667.1 & 690.4 & 654.8 & 621.6 & 629.2 & 691.7 & 665.7 \\
\hline [ISCED-P 1-2] & 706.5 & 732.6 & 757.2 & 679.6 & 738.5 & 609.3 & 682.9 & 673.7 & 687.8 & 732.5 & 656.6 & 648.2 & 660.3 & 706.7 & 692.4 \\
\hline [ISCED-P 3] & 733.4 & 761.1 & 780.9 & 712.1 & 757.7 & 624 & 711.9 & 722.1 & 721.9 & 770.1 & 661.2 & 667.4 & 720 & 758.9 & 723.2 \\
\hline [ISCED-P 4-5] & 749.8 & 798.1 & 810.1 & 744.6 & 786.8 & 655.2 & 722.5 & 748.4 & 729.7 & 774.1 & 687.4 & 690.6 & 774 & 789.4 & 753.4 \\
\hline [ISCED-P 6] & 767.5 & 820 & 836.7 & 776.3 & 811.2 & 660.4 & 739 & 779.5 & 763.1 & 810.5 & 712.1 & 726.4 & 790.8 & 815.4 & 775.3 \\
\hline [ISCED-P 7-8] & 773.1 & 829.6 & 855.3 & 816.7 & 831.2 & 670.5 & 770.2 & 790.6 & 772.8 & 822.4 & 742.6 & 716.6 & 801.6 & 836.3 & 803.8 \\
\hline \multicolumn{16}{|l|}{ Mother's level of } \\
\hline No schooling & 692.1 & 684.2 & 748.6 & 646.7 & 700.9 & 609.5 & 673.7 & 652.3 & 671.5 & 682.9 & 657.7 & 611.5 & 641 & 695.2 & 663.4 \\
\hline [ISCED-P 1-2] & 701.9 & 727.6 & 755.1 & 672.2 & 739 & 608 & 682.4 & 680.7 & 687 & 734.8 & 654.1 & 651.8 & 669.9 & 699.3 & 693.7 \\
\hline [ISCED-P 3] & 728.2 & 758.3 & 781.7 & 711.5 & 761.8 & 624 & 713.7 & 733.2 & 732.9 & 779.1 & 666.8 & 667 & 733.9 & 752.5 & 727.7 \\
\hline [ISCED-P 4-5] & 745.7 & 775.2 & 810.4 & 747.4 & 789.2 & 638.9 & 725.8 & 770.3 & 740.5 & 782 & 693.7 & 694.3 & 778.6 & 791.3 & 762.5 \\
\hline [ISCED-P 6] & 764 & 822.8 & 846 & 773 & 801.2 & 659.6 & 739.5 & 791.4 & 754.7 & 809.8 & 719 & 727.6 & 805.7 & 820.7 & 772.1 \\
\hline [ISCED-P 7-8] & 806.4 & 809.7 & 850.1 & 805.4 & 823.5 & 708.3 & 772.9 & 800 & 765.9 & 820.8 & 733.7 & 731.6 & 817.8 & 823.6 & 801.0 \\
\hline
\end{tabular}

Source: Prepared by the authors, based on data from the Third Regional Comparative and Explanatory Study (TERCE). 